\title{
CONGENITAL MALFORMATIONS
}

5

THE EFFECT OF NIMODIPINE ON LEFT VENTRICULAR FUNCTION AND IIEMIODYNAMICS IN TIIE NEWBORN LAMB. Marcel JU Albers, Erank yan Bel, Robert JMI Klaulz. Pa Steendijk, Jamp Ottenkamp, Lan Bann. Dept. of Pediatrics and Cardiology, Univ. Hosp. Leiden, The Netherlands.

The calcium-channel blocker Nimodipine (Nimo) may mitigate birth asphyxia-induced brain damage. Many calcium-channel blockers negatively affect left ventricular function (contractility, cardiac output [CO]) and lower blood pressure. Nimo-treatment in asphyxiated newborns may be precluded because of the combination of poor postasphyxiated newborns may be precluded because of the combination of poor post-
hypoxic hear function and cercbral autoregulation. In 8 vagotomized newbom lambs we hypoxic heart function and cercbral autoregulation. In 8 vagotomized newborm lambs we
investigated left ventricular (LV) function and systemic hernodynamics before and shortly investigated left ventricular (LV) function and systemic hemodynamics before and shortly
after Nimo administration ( $20 \mathrm{ug} / \mathrm{kg} / \mathrm{iv}$ ). LV contractility and $\mathrm{CO}$ were assessed by after Nimo adininistration ( $20 \mathrm{ug} / \mathrm{kg} / \mathrm{iv}$ ). $\mathrm{LV}$ contractility and $\mathrm{CO}$ were assessed by
measuring LV pressure (tip-manometer) and volume (conductance catheter), using measuring LV pressure (tip-manometer) and volume (conductance catheter), using
inferior caval vein occlusion to obtain slope (Ees) and volume-inlercept $\left(V_{10}\right)$ of the endinferior caval vein occlusion to obtain slop
sysiolic pressure-volume-relationship.

systolic pressure-volume-relationship.
Results: LV-contractility decreased significantly as shown by a decrease in Ees, but CO Results: LV-contractility decreased significantly as shown by a docrease in Tes, but $C O$
did nol significantly change. Mean blood pressure (MBP), systemic vascular resistance (SVR) and heart rate (HR) decreased.

\begin{tabular}{|lccccc|}
\hline after vs before Nimo & Ecs & CO & MBP & SVR & HR \\
$\%$ change \pm SD: & $-32 \pm 26^{*}$ & $-1.6 \pm 19.8$ & $-50 \pm 6^{*}$ & $-4.5 \pm 7^{*}$ & $-11 \pm 8$ \\
\hline
\end{tabular}

ep $<0.05$ (paired t-lest)

Conclusion: Nimo affocts LV function and lowers blood pressure in the newborn tamb. Suggestien: Nimo should be used with caution in the aspliyxiated newborn, because the combination of impaired cerebral autoregulation and suboptimal I.V function with low systemic blood pressure may aggravate brain damage.

\section{6}

CONTROLLED CARDIAC REOXYGENATION REDUCES NITRIC OXIDE (NO) PRODUCTION AND OXIDANT INJURY OF HYPOXEMIC INFANT HEARTS. Michael P. Sherman, Gerald D. Buckberg, Kiyozo Mlorita, Kai Ihnken, and Louis J. Ignarro. Depts. of Pediatrics, Surgery, and Pharmacology. University of California, UCLA Medical Center, Los Angeles, California, U.S.A.

Cardiopulmonary bypass (CPB) is used increasingly to correct cyanotic heart defects during early infancy, but myocardial dysfunction is often seen after surgical repair. This study evaluates whether starting $\mathrm{CPB}$ at a conventional, hyperoxic $\mathrm{pO}_{2}$ causes an uninattended reoxygenation $\left(\mathrm{RcO}_{2}\right)$ injury. We subjected 2-week-old pigs to ventilator hypoxemia $\left[\mathrm{FIO}_{2}=0.06 \& \mathrm{pO}_{2}=25 \mathrm{mmHg}\right.$ ] followed by $5 \mathrm{~min}$ of $\mathrm{ReO}_{2}$ on CPB before instituting cardioplegia. CPB was begun in hypoxemic piglets by either abrupt $\mathrm{ReO}_{2}$ at a $\mathrm{pO}_{2}$ of $400 \mathrm{mmHg}$ [standard clinical practice] or by maintaining a $\mathrm{pO}_{2}=25 \mathrm{mmHg}$ on $\mathrm{CPB}$ until controlling $\mathrm{ReO}_{2}$ with blood maintaining a $\mathrm{pO}_{2}=25 \mathrm{mmHg}$ on $\mathrm{CPB}$ until controlling $\mathrm{ReO}_{2}$ with blood
cardioplegic arrest at a $\mathrm{pO}_{2}=400$. Myocardial $\mathrm{NO}$ production [chemiluminescence measurements of $\mathrm{NO}_{2}{ }^{-}+\mathrm{NO}_{3}-$ in aortic and coronary sinus blood] and conjugitte dicne (CD) generation [spectrophotometric $A_{233}$ measurements of lipid extracts of blood] were assessed during cardioplegic induction. Thirty min after $C P B$, left ventricular end-systolic elastance [Ees, catheter conductance method] was used to determine cardiac function. $\mathrm{CPB}$ and blood cardioplegic arrest caused no functional or biochemical change in normoxic (control) versus hypoxemic hearts. Abrupt $\mathrm{ReO}_{2}$ caused a 10 -fold rise in $N O$ and $C D$ production by the heart with subsequen depression of inyocardial function (Ees $=21 \pm 2 \%$ of control). In contrast, controlled cardiac $\mathrm{ReO}_{2}$ reduced $\mathrm{NO}$ production by $50 \%, \mathrm{CD}$ did not rise, and Ees was $83 \pm 8 \%$ of normal. We conclude controlled $\mathrm{ReO}_{2}$ when starting $\mathrm{CPB}$ to correct cyanotic heart defects may improve nyocardial status post-operatively.

MONITORING CARDIAC FUNCTION IN CIILDREN DURING AND AFTER DOXORUBICIN TIIERAPY. Cristina Azcona, Jesús García-Foncillas, Carme: Villaizán, Pasual Baronia, Maŕa J Garcia-Velloso, Jose Richter, Luis Sierrasestumag:a Dept. of Pediatrics. University Ilospital. University of Navarra. Spain.

In order to study doxorubucin cardiotoxicity in children affected of malignancies an treated with polychemotherapy without mediastinal radiohtherapy, we have assesed cardiac function in 59 children, mean age 16 years (range: 5 to 20 years; 33 males, 24 females) who have received a mean doxorubicin dosage of $340 \mathrm{mg} / \mathrm{m}^{2}$ (range: 123,510 $800 \mathrm{mg} / \mathrm{m}^{2}$ ), performing serial radionuclide angiocardiographies (RNA) at rest and exercise during and after chemotherapy. The following parameters were studied by exercise during and after chemotherapy. The following parameters were studied by
RNA: left ventricular ejection fraction (LVEF), LVEF in the first third of the cardiac RNA: left ventricular ejection fraction (LVEF), LVEF in the first third of the cardiac
cycle, as well as the emptying and lilling Maximal Rate (e/f-Max Rate), Averate Rate
(e/f-Avg Rate) and Time to Peak (e/f-T-P). 20 patients have been followed afier (e/f-Avg Rate) and Time to Peuk (e/f-T-P). 20 patients have been followed after
completion therapy during a mean peried of time of 13.6 months (range 3 in 26.4 completion therapy during a mean period of time of 13.6 months (range 3 io 26.4
months). Multivariate Cox model analysis was used to evaluate the doxorubicin months). Multivariate Cox model analysis was used to evaluate the doxorubicin cardioloxicity by RNA. At cumulative dose ranging from 32() to $420 \mathrm{mg} / \mathrm{m}^{2} \mathrm{LVLF}$ at
$50 \%$ exercise and the emptying and filling Max Rate at $25 \%$ exercise decreised

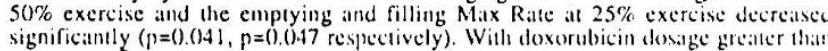
$420 \mathrm{mg} / \mathrm{m}^{2}$ we have found statiscally sipnificant differences in the followin parameters: LVEF at rest, $25 \%$ and $50 \%$ exercise $(p=0.0301, p=(0.028$ and $p=(0.032)$ c/f-Max Rate at rest $(p=() .()-417, p=(0.038)$ and $2.5 \%$ exercise $(p=(0.0) 3.3, p=(),() .5), c / f$

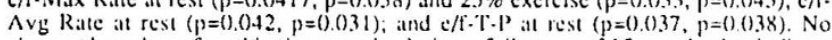
changes have been found in these resulis during a follow-up of 15 months that indicate

inn improvement in cirdliate function.

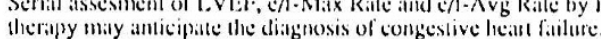

\section{8}

MAINZ CONGENITAL. BIRTM DEFECT MONITORINO SYSTEM Annette Queißer-Luft, Gabriela Hauck, Jürgen Spranger Department of Pediatrica, Johanneg-Gutenberg Univeraity, Mainz, BRD The two most important aims of tho Mainz Congenital Birth Defect Monitoring Syotem were to find "incidence" rates and to look for et lological caunes of congenital malformationo. All bablea born in Malnz underwent atandardized phyolcal and oonographic examination. anamnestic data of family history, enviromental factors, drug exposure etc. were collected. Uaing case controll studies wo looked for apectal correlationa between morphologic defectu and anamneotic data a factors of $r i g k$. The relative risk wa calculated a odda ratio. Regulte: In 1990 and 1991 wo oxaminatod 8430 newborng. 656 ratio. Rebultei In 1990 and 1991 wo oxaminatod 8430 nowborna. 656 systemic localisation of major dofects: skeletal 2,68, urogenital

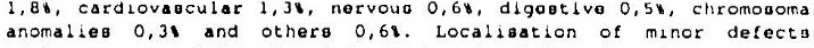
Simian crease 3,9l, Darwinian tubercle 3,88, facial haemangioma 3,28 , auricular tag 3,02 , haemangioma 2,75 , auricular pits 2,38 and others 12,2v. Increased relative riaks (odds ratios) were found for following factorg: Sibling $\left(2,4^{*}\right)$ /parent (1,4) with major
malformation, alcohol abuge $(2,3)$, medication $\left(1,8^{\circ}\right)$ during pregnancy, consanguinity $(1,8)$, diabetea mellitus (mother; 1,7 ), placental insufficiency $(1,4)$ etc. (": statisticaliy significant). Conclusions: The Mainz Congenital Dirth Defect Monitoring Syotem is able to find regional "incidenco" raten and represent a further step longer study period is noceogary for in dopth evalution. comparisong with other regional monitoring byatemg are required.

\section{9}

TERATOGENIC EFFECTS IN $A$ CASE OF MATERNAL TPEATMENT FOR ACUTE LYMPHOBLASTIC LEUKEMIA (ALL)

Andreas Artlicho, Jens Moller ${ }^{\circ}$, Alexander Tschakaloffn, Eberhard Schwinger*, Klaus Kruse ${ }^{\circ}$, Ludwig Gortner ${ }^{\circ}$

Depts. of "Maxillofacial Surgery, Nlluman Genetics and - Paediatrics, Medizinische Universitat zu Lübeck, PRG Acute lymphoblastic leukaemia (ALL) was diagnosed in a 36. year-old and treated with cytarabin, daunorubicin, doxoru. bicin and cytarabin, thioguanin, respectively, in an unrecognized pregnancy at conception and at about 35-37 days p.c. Amniocentesis at 16 weeks of gestation revealed a normal female karyotype.

At delivery, brachycephaly, hypoplasia of supraorbital bony structures and hypotelorism were seen. Hypoplastic nasal root, bilateral choanal atresia and micrognathia caused hypoplasia of naso and oropharynx. There was also bilate. ral aplasia of the radius and hypoplasia of the first ray of the hands. Internally, an atrial septal defect II could be demonstrated. The malformations detected are in accord with the timing of teratogenesis. Neurodevelopment is normal at the age of 8 months. Experience with the use of cytotoxic drugs in pregnancy has so far been limited tc folate antagonists.

\section{DEVELOPMENTAL NEUROLOGY}

\section{0}

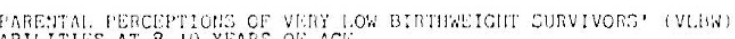
Caroline A Mackens ie and Rotert A Primbak [son. by Prof Ma Tanner]. Department of Paediatric3, Untversity of Sheffield, Shefricld. Ut.

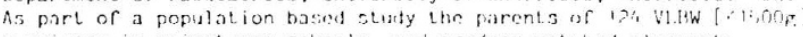

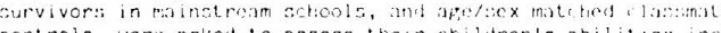
controls, were asted to assess their children's abilitie:s inclusing aspects of school performance, and objective lest scores [BAS and TOMI]. There were significant differences in $10[f=<0.001]$, readiris $[p=<0.02]$ and number $[p=<0.002]$ age ratics and Lomi scores $[p=0.00 !]$ betwenn VI.BW and control children with VLRW survivors performine lor not significantiy different to tho teachers' but the ViBh children's

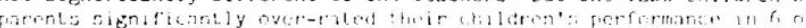
1.2 areas asserset. Wren comparet with objective minasures the Leachers of VLBW and control children were equally accurate in their chiblen were signa ficantiy lese accurate than the teachers or contro: children's parents. Interestingly however the VLBW parents had insight into their children's co-nrdinetion tout hot he educational difficulties. Even at $8-10$ years of age the VLBW children's parents over-estimate their children's ablities 